\title{
Rubella IgG Antibody Measurement
}

National Cancer Institute

\section{Source}

National Cancer Institute. Rubella IgG Antibody Measurement. NCI Thesaurus. Code C103440.

The determination of the amount of the Rubella IgG antibody in a sample. 